\title{
Exploring Labour-Based Approach for Rural Road Maintenance in Nigeria
}

\author{
Olusiyi Ipingbemi \\ Department of Urban and Regional Planning, Faculty of the Social Sciences, \\ University of Ibadan, Ibadan, Nigeria \\ E-mail: odoile2002@yahoo.com
}

KEYWORDS Roads; maintenance; rural development; labour

\begin{abstract}
Rural roads are very cardinal to the socio-economic development of the rural population. They enhanced increased agricultural production, facilitate access to educational and health facilities and provide spatial interaction among rural communities. However, in Nigeria, the condition of rural roads is pathetic. More than $70 \%$ of rural road network is in deplorable condition, which is due partly to inadequate finance, weak technical knowhow of personnel, the use of heavy equipment, official corruption and most importantly lack of political will by the government or its agencies. The consequences are disruption of socio-economic activities of the rural inhabitants. Therefore, the adoption of Labour- Based Approach which is participatory in nature and utilizes local knowledge and initiatives as well as requiring little resources could be the panacea to the protracted deplorable and deteriorating condition of rural roads in the country. The approach will not only improve the quality of life of the rural populace through the creation of job opportunities for the teeming rural population and lowering of transport cost, it will also ensure the sustainable maintenance of rural roads in the country.
\end{abstract}

\section{INTRODUCTION}

Rural roads are very vital to the socioeconomic and political development of rural communities in Nigeria. These roads provide access to schools, clinics, farms, markets, neighouring rural communities among others (ORN, 2003). They also link rural areas to the higher order road network. Thus it is important that they remain open to traffic throughout the year. However, in practical terms these roads are seasonal, particularly during the wet season. The seasonality of roads is due mainly to deterioration occasioned by inadequate maintenance. Continuous rural road deterioration due to poor maintenance has tremendous negative impact on the utility of these roads for enhanced rural development.

Poor roads usually have undesirable effects not only on agricultural production but also on the entire socio-economic development of the rural areas since the rural economy depends largely on the former. Chambers (1983) noted that poor accessibility in rural areas often slows down the diffusion of new technologies and techniques, increases production and marketing costs, reduces spatial interaction and limits access to education and health facilities. It also constrains mobility and aggravates isolation (Burningham and Stankevich , 2005). Studies by Ipingbemi (2001); Ellis (1997); Anderson (1995) and Ogunsanya (1987) have also documented the impact of poor rural roads on the rural economy using various indices.

Therefore, there is the need to ensure regular and adequate maintenance of rural roads in order to facilitate the socio-economic transformation of the rural areas in the country. Over the years, both local government and other agencies such as Agricultural Development Bank (ADP) and Directorate of Food Roads and Rural infrastructure (DFRRI) established by the Federal government and charged specifically with the responsibility of rural roads construction and maintenance have achieved little or no results. The reasons for this failure are not far fetched. One, there is over reliance on heavy machines which are usually manned by personnel who are not capable of carrying out repairs whenever the machines breakdown. Two, the local government under whose jurisdiction the rural roads are directly placed lack necessary funds, qualified personnel and political will for ensuring the continuous maintenance of rural road on a regular basis. In order to transform the poor condition of rural roads in Nigeria, it has become imperative to adopt an approach that would not only allow for maintenance of rural roads on a continuous basis but also affordable within certain scope of maintenance schedules. The option for achieving this is labour based approach to rural road maintenance. This paper therefore is primarily 
concerned with how the benefits of the labour based approach can be harnessed for improved rural roads in Nigeria given the peculiarities of the Nigerian rural road maintenance scheme.

The paper is divided into seven parts including the introduction. Part two examines the role of rural roads in rural development while the development and condition of rural roads in Nigeria was carried out in part three. Part four is an overview of rural road maintenance in Nigeria while part five looks at the Labour-Based Approach and lessons from other countries. Part six discusses how to harness the benefits for Nigeria and part seven is the conclusion.

\section{PART II: RURAL ROADS AND RURAL DEVELOPMENT}

Rural roads are very fundamental to the socioeconomic transformation of the rural areas. They provide links between the rural areas and urban centres, and facilitate the movement of goods, people and service between the rural communities and other villages. In spite of the contribution of rural roads to rural economy, the condition of rural roads in many developing countries, especially in Nigeria is very pathetic. Owen (1960) noted that where roads are impassable, transport costs are high and where marketing is uncertain, progress in agriculture and indeed rural development will be curtailed. Therefore, adequate and reliable rural roads improve rural productivity, enhance physical access, reduce poor people's vulnerability to shocks and stress and enable them to build their livelihood assets (Ellis, 1999 and Davies, 2000).

Various empirical studies have shown the cardinal role of rural roads in socio-economic development of the rural economy. Ahmed and Hossain (1990) found in Bangladesh that rural road development was associated with a $33 \%$ increase in household income and $24 \%$ rise in agricultural production. Similarly, rural roads promote access to educational facilities through increased enrolment rates and improved class attendance (Levy, 1996; Hine et al., 1998; Lebo and Schelling, 2001). For instance, Lebo and schelling (2001) found in Bhutan that the enrolment of girls in primary schools was three times as high in connected villages compared to unconnected ones. In Andhra Pradesh, India, the female literacy rate was $60 \%$ higher in villages with all season road access compared to those with unreliable access.
In the same vein, reliable access to health services (clinics and hospital) contributes directly to human capital that is very important to sustainable rural development. Musa (1999) found in Darfur Region of Sudan that improvements in feeder roads increased the flow of medicine into the area, with the health centres becoming busier and more effective. Child immunization went up by $70 \%$. Where as in the village of Koga that is still inaccessible, child immunization had appalling success rate of $13 \%$.

Rural roads are not only important to agriculture, health and education; they are also very essential for marketing. Mead (1984) observed that good infrastructure in the form of rural access is essential if non-farm enterprises are to break away from and orient their marketing to the outside world. Similarly, Bryd and Zhui (1990) in a survey of rural firms in four counties in china observed that a large majority of the firms sold more than $60 \%$ of their output outside their home province as a result of good roads. Also in India, the placement of bank branches in the rural areas tends to follow the availability of good access.

In addition to improving accessibility, the construction and maintenance of roads provide employment for rural people and provides income generating opportunities for the poor (Dawson and Barwell, 1993; DFID, 2002). For example, DFID (2002) found in Ghana, Madagascar and Thailand that the labour-based approach to rural road maintenance generated between 3-5 times of employment opportunities than capital intensive approach. However, the condition of roads in most developing countries especially in Nigeria is very deplorable.

\section{PART III: THE DEVELOPMENT AND CONDITION OF RURAL ROAD IN NIGERIA}

The federal government's interest in rural roads development predates the country's independence in 1960. The basis of the interest according to the colonial government then was the provision of "better standards of living and greater rural attractions" (Nigeria, 1946). Thus the Ten-year Pre-independence plan made provision for the construction of $24,135 \mathrm{~km}$ of feeder roads and the improvement of further $27,200 \mathrm{~km}$. However rural road construction between 1946 and 1951 of $1,536 \mathrm{~km}$ fell short of planned target by about $95 \%$. 
In both the First (1962-1968) and Second (1970-1975) National Development plans, rural roads construction received little or no attention from the federal government. The government at the center limited its activities to the development of trunk roads, which had little impacts on the lives of rural inhabitants. Although the Second National Development Plan recognized the efforts of local communities in the provision and maintenance of rural infrastructure, especially rural roads (Ikporukpo, 1986).

The third National Development Plan (19751980) witnessed the establishment of various rural development programmes in order to ensure comprehensive rural development. The programmes include among others, Operation Feed the Nation (OFN), Green revolution (GR), River Basin Development Authority (RBDA) and Agricultural Development Projects (ADPs). The ADPs were charged specifically among other things, with the responsibility of constructing and rehabilitating feeder roads in the country. Between 1976 and 1986, ADPs constructed and rehabilitated $9,300 \mathrm{~km}$ of rural roads at the cost of N300m Naira (Lele et al., 1989). However, inadequate funding, weak administration and official corruption made its existence a nominal one in some rural communities in Nigeria.

Recognizing the role of feeder roads in rural transformation, some state governments made concerted efforts to construct rural roads in their areas of jurisdiction. For instance, $23 \%$ of the total road length planned for construction in Ondo State during the 1975-80 plan period were rural roads (Olusogu, 1976). Similarly, of the N183m earmarked for road construction in Lagos State during the 1988 financial year, about $38 \%$ of the amount is for the construction of rural roads (Lagos State, 1988). Furthermore, in the various state governments' policy statements, the objective of road development in rural areas is the enhancement of agricultural production through faster evacuation of agricultural produce. The aim is couched in various forms. For instance, the aim of the Kano state government is to "facilitate produce evacuation and to stimulate increased agricultural production" (Kano State, 1970); an objective that is similar to that of Ondo State (Ondo State, 1975), while that of Bendel State (now Edo \& Delta) is to "open up the agricultural and food production areas” (Bendel State, 1981).
The premium that the Federal Government placed on the provision of rural infrastructure particularly rural roads necessitated the establishment of the Directorate for Food Roads and Rural Infrastructure (DFRRI) in February 1986. This programme is perhaps the most pragmatic road provision approach to date. The Directorate was charged among other things with the responsibility of enhancing rural accessibility. The basic strategy of the DFRRI, according to the Federal Government Policy paper, involves the construction, maintenance and rehabilitation of nation - wide rural feeder roads. Therefore, between 1986 and 1992, DFRRI constructed and rehabilitated about $61,000 \mathrm{~km}$ of feeder roads in Nigeria (Filani, 1993). This figure represents about $51 \%$ of the planned road project for the whole period. In spite of the enormous contribution of DFRRI to feeder roads provision in Nigeria, many rural communities still remained unreached by the time it was merged with the Ministry of Water Resources and Rural Development. This led to the growth of rural roads from $75,000 \mathrm{~km}$ in 1985 to $108,700 \mathrm{~km}$ in 1992 and to about 140,000km in 2000 ( World Bank, 1997 and Schelling, 2000).

While the federal government has been interested in rural roads construction over the years, little attention is paid to their maintenance. Up till now, there is no structure put in place to ensure the regular maintenance of rural roads in Nigeria. The responsibility is still on the local governments which have neither the technical capabilities nor the financial resources to ensure routine maintenance of rural roads. Even the recently created Federal Roads Maintenance Agency (FERMA) is only responsible for Federal roads. The Local Government Roads Maintenance Agency only exists on paper. This poor attitude of different governments over the years towards road maintenance has resulted in unbelievable road deterioration in the country with its attendant implications on Nigerian economy. For example, CBN (2002) estimated N133.5 billion yearly as the total loss to Nigerian economy due to road deterioration. This represents about 5.5\% of the GDP and more than $10 \%$ of the 2004 budget. This amount (annual loss) is too enormous for a country like Nigeria with her fragile economy and whose external debts stand at about $\$ 31.1$ billion (ADB, 2002).

Though the report did not estimate separately the economic costs of poor rural roads to the 
rural or national economy, it is a known fact that poor roads in the rural areas have undesirable effects on agriculture, rural interaction and the overall social-economic development of the rural areas. For example, the 1973 Nigeria Agricultural sector surveys observed that "where there are feeder roads, their poor condition in many areas restrict the ability of farmers to meet growing demand for food and export crops and to reduce the cost of marketing" (Lele, 1989). The 1980 joint report of the federal government and The World Bank also buttressed this point. The report noted that "Whilst the country's primary and secondary roads are being gradually improved to acceptable standards; the feeder road system has suffered from years of neglect and represent the most serious constraint to agricultural development in Nigeria today" (Idachaba, 1980). In the same vein, Aloba (1978) observed that the condition of rural roads disrupts economic activities as well as social interactions in Nigeria rural space. The consequences according to him are rural traffic redundancy and inability of farmers and trader to access rural market centers. The true fact is where roads are impassable resulting in high transportation and marketing inefficiency, progress in agriculture as well as rural development cannot be achieved.

Empirical survey by Ellis (1997) in Tanzania designed to measure the impact of poor road condition on transport charges found that $50 \%$ increase in roughness increased truck charges by $16 \%$ and pick up charges by $30 \%$. Seasonal variation also showed that in wet season passenger fares went up by $60 \%$ and freight charges by $65 \%$. Similarly, Ninnin (1997) found in Madagascar that on poor rural roads during wet season, passenger fares for buses were $70 \%$ higher than dry season fares. In Nigeria, Ipingbemi (2001) observed in Amuro District in Kogi State that passengers pay 3 times per kilometer on untarred rural roads compared to tarred roads. Therefore, there is a need for rural roads to be maintained in order to ensure their sustainability. This is because the sustainability of rural roads hinges on the timely execution of routine maintenance.

\section{PART IV: AN OVERVIEW OF RURAL ROADS MAINTENANCE INNIGERIA}

Road maintenance means preserving and keeping road structures as near as possible in its original state. It consists of correcting deficiencies that have developed as a result of age or use, and taking steps to prevent the development of other deficiencies (World Bank, 1988). It comprises of the activities to keep pavement, shoulders, slopes, drainage facilities and all the structure and property within the road margins in good condition (PIARC, 1994). Road maintenance is vital in order to prolong the life span of roads. A well-maintained road reduces cost of operating vehicles by providing good running surface. Proper maintenance keeps the roads open and ensures greater regularity, punctuality and safety of transport services. Effective road maintenance is the most important prerequisite for safeguarding the investment and ensuring that the road serves its purpose over the anticipated lifetime. It must be noted that a road should not be constructed if maintenance cannot be afforded and managed, especially in Nigeria where rural roads require continuous maintenance throughout the year especially during the raining season.

Road maintenance could be classified into routine, recurrent, periodic as well as emergency (World Bank, 1988; Lebo and Schelling, 2001; CBN, 2002). Routine maintenance comprises of small scale works conducted regularly aimed at ensuring the passability and safety of existing roads in the short-run and to prevent premature deterioration of the roads (PIARC, 1994). Frequency of activities varies but it is generally once or more a week or month. Typical activities include drainage clearing, carriageway repair, clearing of silted ditches, bridges and culverts maintenance, grass cutting and potholes repair among others. Recurrent maintenance on the other hand is required at intervals during the year depending on the topographic and climatic characteristics of the area as well as the volume of traffic. It involves the maintenance of pavements, filling of potholes and grading for unpaved roads.

The periodic maintenance covers activities on the section of the road at regular and relatively long intervals, with the aim of preserving the structural integrity of the road (Burningham and Stankevich, 2005). These operations tend to be large scale, requiring specialized equipment and skilled personnel. They cost more than routine maintenance works and require specific identification and planning for implementation and even design. Lastly, emergency repair takes 
place when road is abruptly cut or bridge washout which could be due to seismic activities.

Over the years, the planning, construction as well maintenance of rural roads has been the responsibility of local governments. Even before the creation of local government, the then native authorities were charged with the responsibility of managing the rural roads in Nigeria. For instance, Onakomaiya (1981) noted that the Native Authorities built and maintained more kilometers of feeder roads than the length of roads $(4,780 \mathrm{~km})$ under the public works department in Lagos. The 1936 Trunk Road Plan was later revised in 1937 and the management of different classes of roads was redistributed between the central and native authorities. For example, while central government was totally responsible for Trunk A roads, the maintenance of Trunk B roads was to be shared with the native authorities 'according to the circumstances of each case'. The native authorities were to pay half of the cost of construction and the maintenance cost of all the roads classified as 'feeder' in the country.

Even in the 1946 - 1955 Ten -year preindependence Plan, the responsibility for the construction of $24,135 \mathrm{~km}$ additional length of rural roads was placed squarely on the shoulders of the native authorities. In actual fact, the lowest tier of government has always been in charge of the feeder road network in Nigeria. Presently, the situation is not different. All roads classified as Trunk C roads (feeder) are under the management of local government (CBN, 2002). This implies that the ownership, planning, construction and maintenance of this network are under the jurisdiction of the local government. At present, the local government is responsible for about $140,000 \mathrm{~km}$ length of roads in the country, representing about $60 \%$ of the total road network in Nigeria. More than $70 \%$ of the rural roads are in poor condition (Adeniji, 2000; Oyesiku, 2002). That is about three and six times of the length of road being responsible for by the States and Federal Government respectively. Is this not amazing, if we have to put the financial resources and technical capability of local government viz - viz the length of roads network she has to maintain?. It is therefore not surprising that the performance of the local governments in road maintenance has been unsatisfactory over the years. Onakomaiya (1981) observed that the native authorities could not deliver satisfactorily their road network programme because they had neither the funds nor the personnel and equipment required to cope with the gigantic task imposed on them. Reasoning along the same line, Filani (1987) wondered why agency, which is least able to construct and maintain roads in terms of funds and personnel, has the greatest responsibility. It is therefore, imperative to adopt a strategy that utilizes traditional knowledge and local initiative, requires little resources and participatory in nature in order to ensure sustainable maintenance of rural roads in Nigeria. These attributes which are inherent in Labourbased technology makes the approach a preferred one.

\section{PART V: LABOUR -BASED APPROACH}

\subsection{The Concept of Labour Based Approach}

Labour based approach is a structured method of providing or maintaining rural infrastructure (especially rural roads) to specified standards (ILO/ASIST, 2003). The concept is based on the principle of using manual labour to complete tasks otherwise done by the machine. These tasks include clearing of trees and bushes on the road alignment, removal of topsoil, evacuation of soil along the sides of the road to form the side drains among others. These tasks are completed by the use of hand tools such as hoes, shovels, spades, rakes and wheel-barrow. These are common tools used in agricultural activities and the rural people are familiar with them.

The labour based approach is carried out through a 'lengthman system' where small and manageable tasks are allocated to individual workers according to priorities throughout the season. A labourer is employed for each section of road typically $1-2 \mathrm{~km}$ in length. A supervisor provides the tools and at the same time monitors the condition of roads, directs operations, makes reports and authorizes payment for satisfactory work. The worker lives close to the location of maintenances activities and may therefore not require any transport. The 'lengthman system' is desirable because a continuous maintenance of the entire road can be guaranteed at all times. This system would be particularly useful in southern part of Nigeria where the cleaning of the culverts and mitre drains need to be carried out on a regular basis especially during the wet season. 
The preference of this approach is based on the fact that most local government councils in the country do not have the financial muscle and the required personnel to embark on equipment (machine) based approach. The continuous use of heavy machines for the construction and maintenance of rural roads has been found to have implications on foreign exchange and results in significant more environmental damage due to the movement of large machines. These include fuel spills, dust, and excessive clearance of vegetation. Another problem relates to the equipment being used itself. These are fuel shortage, delays in procurement for both equipment and spare parts, inappropriate type of equipment, lack of understanding of equipment used and poorly trained and illmotivated operators. Also, the use of labour based is very necessary because of the difficulties inherent in importing, operating and maintaining heavy machines. Similarly, roads built and maintained by labour based approach are more durable because of greater attention to details during maintenance (Republic of Mozambique/ UNDP/SIDA, 2002 ).

\subsection{Lessons from Other Countries}

The glowing success of labour based approach to rural roads maintenance in many developing countries attest to its application in Nigeria. A few of these countries will be considered in this section.

Peru provides a good example of a country that has successfully implemented labour-based approach for rural roads works. Peru has a total rural road network of $46,909 \mathrm{~km}$, equivalent to $60 \%$ of the country's total road network (Edgar, 2003). Routine maintenance of this rural road network is carried out by micro-enterprises. These micro-enterprises are created, trained and contracted by PROVIAS - Rural (Peru's autonomous Rural Road Programme) with the objective of guaranteeing year-round sustainability for the rural road network. The workers are from communities close to the stretch of the road concerned. They are responsible for routine maintenance such as filling of potholes, clearing mitre drains, culverts and other elements of the drainage system using basic hand tools and wheelbarrows. Each enterprise consists of approximately 12 associates and is responsible for a stretch of $25 \mathrm{~km}$ for which they receive an average of US $\$ 750$ per kilometer per year. This programme has provided permanent employment for over 5,000 rural poor. In the same vein, Eric (2002) noted that Kenya adopted labour-based approach for rural roads maintenance in 1999 to cover four districts in her road project tagged "Roads 2000". A total of 137 contractors (comprising an average of 10 trainees' members) have benefited from this programme. These contractor's trainees have maintained a total of $900 \mathrm{~km}$ length of road. While in Mozambique over $5000 \mathrm{~km}$ of rural roads were upgraded between 1992 and 2000 using labour-based approach (Republic of Mozambique/UNDP/SIDA, 2002). It also created about 8 million worker-day of employment and more than 40,000 rural people worked on the programme.

Also, in Madagascar a well-documented result of labour-based technique when compared with conventional equipment based technology showed that, labour based approach is $30 \%$ cheaper. It also reduced foreign exchange by $30 \%$ and created between 3-5 times more employment opportunities per unit of investment (DFID 2002). To this end, the Government of Madagascar with the support of World Bank have decided to mainstream the labour-based approach by shifting a sum of US $\$ 50 \mathrm{~m}$ to fund rural roads executed with labour-based technology. The belief is that this will generate between 100-150 contracts annually at US \$75,000 - US \$120,000 for each labour-based contractor (ILO/ASIST, 2003). Similarly, it is expected that the programme will also generate some 16 million workers- days of employment between 2003 and 2008, this being equivalent of 16,000 full time jobs per year over the next five years. Lessons above have shown that labour based approach to rural road maintenance is capable of generating employment that will act as a catalyst for improved rural productivity.

\section{PART VI: HARNESSING THE BENEFITS OF THE APPROACH FOR NIGERIA}

The benefits of labour-based approach to the rural economy are numerous, however, only few of them will be considered here. The approach allows the creation of labour markets in areas where these were underdeveloped or nonexistent, and it generates direct permanent employment for a significant percentage of the local communities (most especially the rural poor). And 
since most of the rural inhabitants stay within their localities the wages earned will be spent in their communities, which will result in an important impulse for the local economy as well as subsequent multiplier effects. ILO/ASSIST (2003) noted in Mozambique that the use of labour based approach led to the creation of 8 million worker-days employment in the country between 1994 and 2000.

Similarly, it can also result in the generation of indirect employment for many rural people if certain percentage of the wages earned is kept as "Funds". Such funds can be used for productive projects in the community such as poultry keeping, communal shops, purchase of livestock etc. This will result in additional indirect employment within the community. For instance, Contreras and Cartier (2004) observed in Peru that the Micro-enterprises used Social Funds to finance community activities such as cleaning works, painting of schools and the installation of drinking water. The communities in turn helped the micro-enterprises in certain road maintenance activities through community efforts. The Fund can also serve as a contingency fund to cover late payment of salaries/wages and as well as act as a type of health insurance fund. In the same vein, where feasible and cost effective, the application of labour based approach to rural road maintenance results in a substantial savings in foreign exchange and an increase in the utilization of local resources which in turns stimulates the local economy; since it will not be necessary to import machine, material or personnel from abroad.

Most of the roads infrastructures constructed or maintained through the use of heavy equipment are not sustainable because it alienated the beneficiaries from actively participating in such infrastructure, hence their failure. However, labour based approach is a costeffective method of producing appropriate road assets that are durable, sustainable and of good quality. This is because the beneficiaries of the development projects are allowed to actively participate in the identification, prioritization and implementation of road infrastructure asset that addresses the access needs of members of the rural community. Also, the involvement of rural people in this type of programme promotes local participation; create sense of ownership as well as enhancing capacity building and local empowerment through skills transfers. It will also sharpen their technical abilities and entrepreneurial skills and enable them to initiate various productive projects on their own. This is crucial to the future operation and maintenance of the asset.

Furthermore, the improved state of roads ensures easier access to markets and public services such as education and health facilities. Travel costs and time are reduced as well as transaction costs. The availability of public transport services will also increase. However, the overall benefits are rural roads sustainability and poverty reduction in the rural areas.

\section{CONCLUSION}

Rural roads in Nigeria are cardinal to socioeconomic transformation of rural areas. They are important to increased agricultural productivity and facilitate spatial interaction among members of rural communities. However, the deplorable condition of rural roads in the country has reduced their utility to the generality of rural population. The local government and other agencies (ADP \& DFRRI) created and charged with the responsibility of rural roads maintenance have not lived up to expectation over the years .The reasons for their poor performance are not far fetched. One, the over reliance on heavy machines that are manned by inexperience and unqualified personnel affected their activities tremendously. Two, the local government is financially constrained to ensure that the rural roads are regularly maintained. Three, even when funds are available, the shoddy manner in which contracts are awarded and executed as well as the way money is disbursed by local government officials left much to be desired. The adoption of labour-based approach could be a panacea to this protracted problem. The approach is based on the principle of using manual methods (labour) to complete tasks otherwise done by machine.

Labour based approach is valid in rural areas in Nigeria because this is where we have a high level of unemployment, scarce capital, cheap labour, low wages and deepened poverty. In the same vein, the type of work associated with labour-based method is simple, and local people are familiar with the implement/tools used for road works; shovel, cutlass, hoe etc. For instance, spot improvement interventions are small scale. The tasks to be undertaken also require detail 
attention and do not need heavy equipment. Labour- based approach is regarded in many quarters as "one grain-four harvests". That is, it creates employment opportunities for rural inhabitants. The labour-based approach also lower transport costs through routine maintenance of rural roads. Money is ploughed back in to the rural economy since most of the wages earned are spent in the rural communities. Finally, it ensures the sustainability of rural roads and improves the quality of life of the rural inhabitants.

\section{REFERENCES}

ADB 2002. Selected Statistics on African Countries. Abidjan: African Development Bank

Adeniji, K. 2000. "Transport Challenges in Nigeria in the next two Decades." Keynote Address delivered at the $5^{\text {th }}$ National Council on Transportation held in Abuja between $29^{\text {th }}$ and $31^{\text {st }}$ August, Abuja .

Ahmed, R and M Hossain. 1990. Development Impact of Rural Infrastructure in Bangladesh. Washington DC: IFPRI

Aloba, O. 1978. "Factors Influencing Freight Charges in Nigeria." Paper presented at the I.U.G. regional Conference Commission of Freight Transport in the Developing Economy, University of Ife, Ile Ife , July 22-27

Anderson, M. 1995. "Why are Rural Roads Important? Assessing the Benefits." New World Transport 1995. The International Review of Transport Solutions in Developing Countries.

Bendel State. 1981. Fourth National Development Plan, 1981-1985, Benin City.

Burningham, S. and N. Stankveich. 2005. "Why Road Maintenance is Important and How to get it Done." World Bank Technical Note TRN-4, June 2005

Byrd, W and N Zhui 1990. "Market Interactions and Industrial Structures", in W. Byrd and Q. Lin (eds.), China Rural Industry: Structure Development and Reforms. New York: Oxford University Press

Chambers, R. 1983. Rural Development. Putting the Last First. London: Longman.

Central Bank of Nigeria (CBN). 2002. Highway Maintenance in Nigeria: Lessons fron Other Countries. Abuja: CBN

Contreras, J. and V.D.S. Cartier. 2004. "Routine Road Maintenance Micro-enterprise - an Option for Employment Generation and Capacity Building.' ILO/ASSIST Bulletin No. 17 Pg 6\&7. Geneva: ILO

Davies, A. 2000. "Transport and Sustainable Rural Livelihoods in Zambia: A case study." Eight Regional Seminar for Labour Based Practitioners. Cairo, Egypt.

Dawson, J. and I, Barwell. 1993. Roads are not Enough. New Perspectives on Rural Transport Planning in Develkoping Countries. London: IT Publications.

DFID. 2002. Making Connections: Infrastructure for Poverty Reduction. Consultation Document. London: DFID
Ellis, S. 1997. Rapid Appraisal Techniques for Identifying Maintenance Priorities on Low Volume Roads. TRL Report PR/OSC/122/97. Crowthorne TRL.

Ellis, C. I. 1999. "The Role of Secondary Rural Roads in Economic and Social Development in Developing Countries." Keynote paper presented at $21^{\text {st }}$ World Road Congress PIARC, Kuala Lumpur, Malaysia.

Edgar, R 2003. "Microenterprise-based road maintenance in Peru." ILO/ASIST Bulletin No15 March 2003, PP 15-16.

Eric, G. 2002. "Putting Routine Maintenance First: Experiences from Routine Maintenance using Small Scale Contracting In Coast Province, Kenya." ILO/ ASIST Bulletin No 3 March 2002.Geneve: ILO/ ASIST. PP 6-8.

Federal Republic of Nigeria. 1946.A Ten -year Plan of Development and Welfare for Nigeria. Lagos: Government Document.

Federal Republic of Nigeria 1962. First National Development Plan. Lagos: Federal Ministry of Economic Development.

Federal Republic of Nigeria. 1970. Second National Development Plan, 1970-1974. Lagos: Federal Government Printer.

Federal Republic of Nigeria 1975. Third National Development Plan, 1975-1980 vol 1. Lagos: Central Planning Office.

Filani, M. O. 1993. "Transport and Rural Development in Nigria." Journal of Transport Geography, 1(1): 248-254.

Hine, J., Nelson V. and P.A.K. Greening 1998. "A project to improve feeder and community access in Southern province of Zambia." An initial assessment TRL draft.

Idachaba, F. S. 1980. The Green Revolution: A Food Production Plan. Lagos: Federal Ministry of Agriculture

Ikporukpo, C.O.1986. "The Management of the Rural Transportation Problem in Nigeria". The Quarterly Journal of Administration, 21(1\&2): 57-71.

Ipingbemi, O. 2001. Rural Transportation and Poverty Alleviation in Amuro Distric, Kogi State. Unpublished M.Sc. Thesis. Dept of Geography, OAU, Ile-Ife.

ILO/ASIST 2003. "Labour Based Technology for Poverty Reduction." ILO/ASIST Bulletin No. 15 March PP 2-4.

Kano State of Nigeria 1970. Development Plan, 19701975., Kano: Economic Planning Division.

Lagos State 1988. Budget Speech by the Governor of Lagos State. January 11, 1988.

Lebo, J. and D. Schelling 2001 "Design and Appraisal of Rural Transport Infrastructure: Ensuring Basic Access for Rural Communities." World Bank Technical Paper No. 496. Washington DC: The World Bank.

Lele, U, V. Bindlish and J. Gavaria. 1989. "The Rural Roads Question in Nigeria's Agricultural Development." MADIA Discussion Paper 10. Washington DC: The World Bank.

Levy, H. 1996. Kingdom of Morocco - Evaluation Report- Socio-economic Influence of Rural Roads Operation Evaluation Department .Washington DC: The World Bank. 
Mead, D. 1984. "Of Contracts and Subcontracts: Small Firms in Vertically Disintegrated Production/ Distribution Systems in LDC." World Development, 12(11\&12): 1095-1106.

Mbagwu, T.C. 1981. "Transportation constraints to rural-urban flows of agricultural food products. The example of Owerri area", (Pp. 243-264), in S. O. Onakomaiya and N. F. Ekanem (eds.), Transportation in Nigeria National Development. Ibadan: NISER.

Musa, M. S. 1999. "Impact of Feeder Roads in Jebel Si, Rural Council Area on Food Security Balancing The Load." Proceedings Nigeria. A Ten-year plan of development and welfare for Nigeria. Lagos: Government Printer.

Ninnin, B. 1997. Transport and Development. A Madagascar Public Works Ministry. INRETS.

Ogunsanya, A. A. 1987. "Rural Accessibility Problems and Human Resources Development : Case study from Nigeria." Journal of Rural Studies, 3(1): 31-42.

Ojabo , L. 2004. "All Nigerian Roads must be good at all time." The Daily Sun, Thursday January, 8, 2004.

Onakomaiya, S.O. 1981. Highway Development in Nigeria: A Review of Policies and Programmes 1900-1980. NISER Monograph Series No 5. Ibadan: NISER

Ondo State. 1975. Third National Development Plan, 1975-80. Akure.
Olusogu, J. R. 1978. "Highways and farm access development in Ondo State." Proceedings of Workshop on Development Planning Strategy in Ondo State For 1980s. Akure: Ministry of Finance and Economic Development. Pp. 201-208.

Overseas Road Note 2003. Management of Rural Roads Networks. ORN 20. Crowthorne, TRL.

Owen, O. 1966. "Transport and Technology" in 6 FROMA (ed.), Transport Investment and Economic Development. Washington DC: The Brookling Institution.

Oyesiku, O.O. 2002. "From Womb to Tomb." 24 $4^{\text {th }}$ Inaugural Lecture, Olabisi Onabanjo University, Ago-Iwoye, Ogun State.

PIARC (World Road Association) 1994. International Road Maintenance Book: Practical Guidelines for Rural Road Maintenance. Vol 1 of IV: Roadside Areas and Drainage. ODA and TRL.

Rannis, G., F. Stewart and E. Angeles-Reyes. 1990. Linkages in Developing Economics: A Philippines Study. San Francisco: The International Centre for Economics Press.

Republic of Mozambique / UNDP/SIDA 2002. Mozambique: Re-opening Mozambique: Lessons Learned from the Feeder Road Programme. UNDP

World Bank. 1988. Road Deterioration in Developing Countries: Causes and Remedies. Washington DC: The World Bank 